\title{
EFFECT OF POMEGRANATE EXTRACT GALLIC ACID ON THE PROLIFERATION OF PROSTATE CANCER CELLS BY PROMOTING THE EXPRESSION OF IGFBP7
}

\author{
FAN, G. F. ${ }^{1 *}-$ YU, Z. G. ${ }^{2}-$ LIANG, Y. B. $.^{1,3}-$ XU, Z. G. ${ }^{1}-$ TANG, J. $^{1}$ \\ ${ }^{1}$ Hefei Education Master Studio, Hefei Technology College, Hefei 238000, China \\ ${ }^{2}$ Hefei Technology College, Hefei 238000, China \\ ${ }^{3}$ Shanghai Haihong Industry (Group), Chaohu Jinchen Pharmaceutical Co., Ltd., Hefei 238000, \\ China \\ *Corresponding author \\ e-mail:fgaofu@163.com
}

(Received 20 $0^{\text {th }}$ Jan 2020; accepted $2^{\text {nd }}$ Jul 2020)

\begin{abstract}
Objective: Pomegranate extract gallic acid inhibits the proliferation of prostate cancer PC-3 cells by promoting IGFBP7 expression. Methods: PC-3 cells were divided into six groups: control group (NC), blank control group (BL), IGFBP7 overexpression group (IGFBP7), Pomegranate extract gallic acid group $(5.0 \mu \mathrm{mol} / \mathrm{L}, 10.0 \mu \mathrm{mol} / \mathrm{L}, 20.0 \mu \mathrm{mol} / \mathrm{L})$. Cell proliferation was detected by MTT assay; apoptosis of each group was analyzed by flow cytometry; the expression levels of IGFBP7, AKT and mTOR were assessed by Western blot. Results: The proliferative plural of PC-3 cells in IGFBP7 group and pomegranate gallic acid group were significantly lower than those in NC and BL groups $(\mathrm{P}<0.05)$. The pomegranate gallic acid group showed dose- dependence. The results of Western blot analysis showed that IGFBP7 group and The levels of IGFBP7 in the pomegranate extract gallic acid group were significantly higher than those in the NC and BL groups $(\mathrm{P}<0.05)$, while the levels of AKT and mTOR plural were significantly lower than those in the $\mathrm{NC}$ and $\mathrm{BL}$ groups $(\mathrm{P}<0.05)$. Pomegranate extract gallic acid showed dose-effect further elaborated within each group. Conclusion: Pomegranate extract gallic acid can inhibit the expression level of AKT/mTOR protein by enhancing the expression level of IGFBP7, thereby inhibiting the AKT/mTOR signaling pathway, the result is an inhibitory effect on the proliferation of prostate cancer PC-3 cells.
\end{abstract}

Keywords: pomegranate extract gallic acid, IGFBP7 protein, AKT/mTOR protein, $P C-3$ cell, prostate cancer

\section{Introduction}

Pomegranates (Punica granatum L.) are widely distributed and are cultivated in large quantities in China, India and Asia, Africa, Europe along the Mediterranean Sea, and California, USA. Among them, the key production areas of Chinese pomegranates are mainly fruit production, including Lintong, Ganxian, and Sanyuan in Shanxi Province, Zaozhuang in Shandong Province, Suzhou, Nanjing, Xuzhou, Pi xian in Jiangsu Province, Mengzi, Qiaojia, Jianshui, Chenggong in Yunnan Province, Yecheng Pomegranate in Xinjiang, Huili in Sichuan, Huaiyuan in Anhui Province, Xiaoxian, Suixi, Chaoxian (now Chaohu area of Hefei City), etc., as a common fruit, has many biological uses in areas like edible, medicine and health care, especially against cancer, cardiovascular and cerebrovascular diseases, liver disease and inflammatory infection certain treatment and prevention effects. The effective components of pomegranate are mainly the polyphenols in its fruit, and the pomegranate extract gallic acid is one of the main phenolic substances. It had many biological activities such as antibacterial, antiinflammatory, anti-oxidation, liver function protection and anti-tumor. Function (Feng, 
2014; Lee, 2017; Pang, 2017; Rasool, 2010). Recent studies have shown that polyphenols have a positive significance in inhibiting the proliferation and migration of tumor cells (Panth, 2017; Momtaz, 2017). At present, prostate cancer is the primary factor that endangers male health in the world. The incidence of males is the second in the world, and the incidence of developed countries is the first. It ranks among the highest rates of male genitourinary malignant tumors (Wang, 2019). In this study, the mechanism of action of pomegranate extract gallic acid on prostate cancer tumor cells was explored. Different concentrations of pomegranate extract gallic acid were used to treat prostate cancer PC-3 cells. This provides a theoretical basis for the development and application of pomegranate extract gallic acid.

\section{Materials and methods}

\section{Cell line}

The prostate cancer PC-3 cell line was purchased from the Shanghai Cell Bank of the Chinese Academy of Sciences.

\section{Experimental drugs and related reagents}

Pomegranate extract gallic acid (GA) was purchased from Nanjing Surang Pharmaceutical Technology Development Co., Ltd., with a mass fraction of 99\%(China); fetal bovine serum, DMEM high glucose medium, and trypsin were purchased from Sigma (USA); rabbit anti-human IGFBP7 was purchased from Abcam (UK); Annexin V/PE Apoptosis Detection Kit, MTT Cell Proliferation and Cytotoxicity Assay Kit from Shanghai Biyuntian Biotechnology Co., Ltd (China).

\section{Experimental methods}

PC-3 cells were divided into six groups: control group (NC), blank control group (BL), IGFBP7 overexpression group (IGFBP7), $5.0 \mu \mathrm{mol} / \mathrm{L}$ pomegranate extract gallic acid group $(5.0 \mu \mathrm{mol} / \mathrm{L} \mathrm{GA}), 10.0 \mu \mathrm{mol} / \mathrm{L}$ pomegranate extract gallic acid group (10.0 $\mu \mathrm{mol} / \mathrm{L} \mathrm{GA})$, and $20.0 \mu \mathrm{mol} / \mathrm{L}$ pomegranate extract gallic acid group $(20.0 \mu \mathrm{mol} / \mathrm{L} \mathrm{GA})$. The NC group was cultured in DMEM high-glucose medium; the BL group was transfected with blank plasmid in PC-3 cells and cultured in DMEM high glucose medium (Johnson, 2018; Zephania, 2019); IGFBP7 overexpression group was transfected with IGFBP7 plasmid on PC-3 cells. The cells were cultured in DMEM high glucose medium. The pomegranate extract gallic acid group was not transfected with PC-3 cells. The concentration of pomegranate extract gallic acid in the medium was 5.0 $\mu \mathrm{mol} / \mathrm{L}, 10.0 \mu \mathrm{mol} / \mathrm{L}$ and $20.0 \mu \mathrm{mol} / \mathrm{L}$, respectively. The culture medium of each group was incubated for $24 \mathrm{~h}$ in an incubator with $5.0 \% \mathrm{CO}_{2}$ and a temperature of $37^{\circ} \mathrm{C}$.

\section{IGFBP7 transfected cells $(\mathrm{Hu}, 2017)$}

PC-3 cells were inoculated into 24-well plates, and the cells were observed to be in good condition after $48 \mathrm{~h}$, that is, adherent growth, when the cell fusion rate reached $60 \%$ to $80 \%$, prepared for transfection. Lipofectamine TM 2000 transfection kit (Invitrogen, USA), IGFBP7 and internal reference primers were designed and synthesized by Shanghai Shenggong Biotech Co., Ltd. to transfect PC-3 cells and stably express IGFBP7 gene. 


\section{MTT assay to detect cell proliferation (Maleki, 2020)}

Six groups of cells were taken, trypsinized, and inoculated into a 96-well plate to adjust the cell density to $1.5 \times 10^{4} /$ well, and continue to incubate. The cultures were stopped at 12, 24 and $48 \mathrm{~h}$, and $20 \mu \mathrm{L}$ of MTT was added. The culture was continued for $4 \mathrm{~h}$. $150 \mu \mathrm{L}$ of dimethyl sulfoxide was added and shaken for $10 \mathrm{~min}$. The OD value of each well was measured by a microplate reader at $570 \mathrm{~nm}$.

\section{Apoptosis detection apoptosis rate (Guo, 2016)}

PC-3 cells in logarithmic growth phase were inoculated into 96-well plates for $24 \mathrm{~h}$. The NC group, the BL group and the IGFBP7 transfection group were cultured in DMEM medium, and the treatment group was added with $5.0 \mu \mathrm{mol} / \mathrm{L}, 10.0 \mu \mathrm{mol} / \mathrm{L}$ and $20.0 \mu \mathrm{mol} / \mathrm{L}$ pomegranate gallic acid for $24 \mathrm{~h}$, and the Annexin V/PE apoptosis detection kit was used. The cells were prepared in strict accordance with the instructions and the apoptosis rate of the above six groups of prostate cancer PC-3 cells was analyzed by BD FACSCanto II flow cytometry.

\section{Western blot detection of total protein extracted from each group of cells (Wei, 2016)}

The protein concentration was determined by the $\mathrm{BCA}$ method. After treatment with different concentrations of pomegranate gallic acid for $24 \mathrm{~h}$, PC-3 cells were collected and washed twice with cold PBS. The resulting cells were then lysed on ice for $10 \mathrm{~min}$. After centrifugation at $12000 \times \mathrm{g}$ for $10 \mathrm{~min}$ at $4{ }^{\circ} \mathrm{C}$, the supernatant was transferred to a fresh tube and stored at $-70{ }^{\circ} \mathrm{C}$. The protein concentration was determined by using a BCA test kit, and $50 \mu \mathrm{g}$ of each well was loaded, and the sample was separated by SDS-PAGE at a concentration of $12 \%$, transferred, blocked, and added with a primary antibody at $4{ }^{\circ} \mathrm{C}$ overnight. Wash the membrane, add the secondary antibody, incubate for $1 \mathrm{~h}$ at room temperature, and wash the membrane with TBST. The band gradation value was determined by adding the illuminant using ImageJ software.

\section{Statistical processing and analysis (Guo, 2016)}

The results were processed and statistically analyzed using the SPSS19.0 statistical software package. The mean \pm standard deviation $(\bar{X} \pm \mathrm{s})$ was used. The pairwise comparison was performed by LSD-t test; the count data was expressed by the rate value. The comparison was performed using the $\chi 2$ test. $\mathrm{P}<0.05$ indicates that the difference was statistically significant.

\section{Results}

\section{PC-3 cell inhibition results}

The results of six groups of cells after different treatments inhibited PC-3 cells. The IGFBP7 overexpression group and the three GA groups $(5.0 \mu \mathrm{mol} / \mathrm{L}$ group, $10.0 \mu \mathrm{mol} / \mathrm{L}$ group and $20.0 \mu \mathrm{mol} / \mathrm{L}$ group) were significantly higher than the $\mathrm{BL}$ and NC group; and compared with the BL and NC groups, there are statistical differences between the three GA groups $(\mathrm{P}<0.05)$, IGFBP7 overexpression group and the three GA groups showed obvious time-effect relationship and dose-effect relationship (see Table 1). 
Table 1. Inhibition of PC-3 cells in six groups after different treatments $(\bar{x} \pm s)$

\begin{tabular}{c|c|c|c|c}
\hline \multirow{2}{*}{ Groups } & Number of & $\mathbf{1 2 ~ h}$ & $\mathbf{2 4 ~ h}$ & $\mathbf{4 8 ~ h}$ \\
\cline { 2 - 4 } & samples & OD value & OD value & OD value \\
\hline NC group & 5 & $0.45 \pm 0.02$ & $0.56 \pm 0.03$ & $0.87 \pm 0.03$ \\
BL group & 5 & $0.46 \pm 0.02$ & $0.57 \pm 0.03$ & $0.85 \pm 0.04$ \\
IGFBP7 transfection group & 5 & $0.21 \pm 0.03 \mathrm{a}, \mathrm{b}$ & $0.25 \pm 0.08 \mathrm{a}, \mathrm{b}$ & $0.33 \pm 0.08 \mathrm{a}, \mathrm{b}$ \\
$5.0 \mu \mathrm{mol} / \mathrm{L}$ group & 5 & $0.54 \pm 0.03 \mathrm{a}, \mathrm{b}$ & $0.59 \pm 0.08 \mathrm{a}, \mathrm{b}$ & $0.69 \pm 0.08 \mathrm{a}, \mathrm{b}$ \\
$10.0 \mu \mathrm{mol} / \mathrm{L}$ group & 5 & $0.39 \pm 0.02 \mathrm{a}, \mathrm{b}, \mathrm{aa}$ & $0.45 \pm 0.08 \mathrm{a}, \mathrm{b}, \mathrm{aa}$ & $0.48 \pm 0.08 \mathrm{a}, \mathrm{b}, \mathrm{aa}$ \\
$20.0 \mu \mathrm{mol} / \mathrm{L}$ group & 5 & $0.26 \pm 0.04 \mathrm{a}, \mathrm{b}, \mathrm{aaa}$ & $0.30 \pm 0.05 \mathrm{a}, \mathrm{b}, \mathrm{aaa}$ & $0.46 \pm 0.05 \mathrm{a}, \mathrm{b}, \mathrm{aaa}$ \\
\hline
\end{tabular}

a: $\mathrm{P}<0.05$, the difference from the NC group was statistically significant $\mathrm{b}: \mathrm{P}<0.05$, the difference from the BL groups was statistically significant aa: $\mathrm{P}<0.05$, the difference was statistically significant compared with the $5.0 \mu \mathrm{mol} / \mathrm{L}$ GA group aaa: $\mathrm{P}<0.05$, the difference was statistically significant compared with the $10.0 \mu \mathrm{mol} / \mathrm{L}$ GA group

\section{Apoptosis detection}

Compared with the $\mathrm{NC}$ group $(4.84 \pm 0.45)$ and the $\mathrm{BL}$ group $(5.16 \pm 0.38)$, the apoptosis rates of PC-3 cells in the IGFBP7 overexpression group and the three GA groups $(40.52 \pm 1.76, \quad 15.98 \pm 1.89, \quad 30.36 \pm 1.7$ and $39.04 \pm 1.43)$ increased significantly. Compared with NC group and BL group, the difference between IGFBP7 overexpression group and the three GA treatment group was statistically significant $(\mathrm{P}<0.05)$, and there was a significant dose-effect relationship between with the three GA groups. The result is shown in Figure 1 .

\section{Comparison of six groups of IGFBP7 protein levels}

Western blot method was used to detect the effect of different treatments on the expression of IGFBP7 protein in PC-3 cells. Compared with NC and BL groups, the results showed that the expression levels of IGFBP7 protein by IGFBP7 overexpression group and the three GA groups $(5.0 \mu \mathrm{mol} / \mathrm{L}$ group, $10.0 \mu \mathrm{mol} / \mathrm{L}$ group and $20.0 \mu \mathrm{mol} / \mathrm{L}$ group $)$ was significantly increased; and compared with BL and NC groups, the three GA groups are statistical differences between groups $(\mathrm{P}<0.05)$. The result is shown in Figure 2.

\section{Comparison of six groups of AKT protein levels}

Western blot method was used to detect the effect of different treatments on the expression of AKT protein in PC-3 cells. Compared with NC and BL groups, the results showed that the expression levels of AKT protein by IGFBP7 overexpression group and the three GA groups $(5.0 \mu \mathrm{mol} / \mathrm{L}$ group, $10.0 \mu \mathrm{mol} / \mathrm{L}$ group and $20.0 \mu \mathrm{mol} / \mathrm{L}$ group $)$ were significantly reduced. And compared with the BL and NC groups, the three GA groups are statistical differences between groups $(\mathrm{P}<0.05)$. The result is shown in Figure 3.

\section{Comparison of six groups of mTOR protein levels}

Western blot method was used to detect the effect of different treatments on the expression of mTOR protein in PC-3 cells. Compared with NC and BL groups, the results showed that the expression levels of mTOR protein by IGFBP7 overexpression group and the three GA groups $(5.0 \mu \mathrm{mol} / \mathrm{L}$ group, $10.0 \mu \mathrm{mol} / \mathrm{L}$ group and $20.0 \mu \mathrm{mol} / \mathrm{L}$ group $)$ were significantly reduced. And compared with the BL and NC groups, the three GA groups are statistical differences between groups $(\mathrm{P}<0.05)$. The result is shown in Figure 4. 

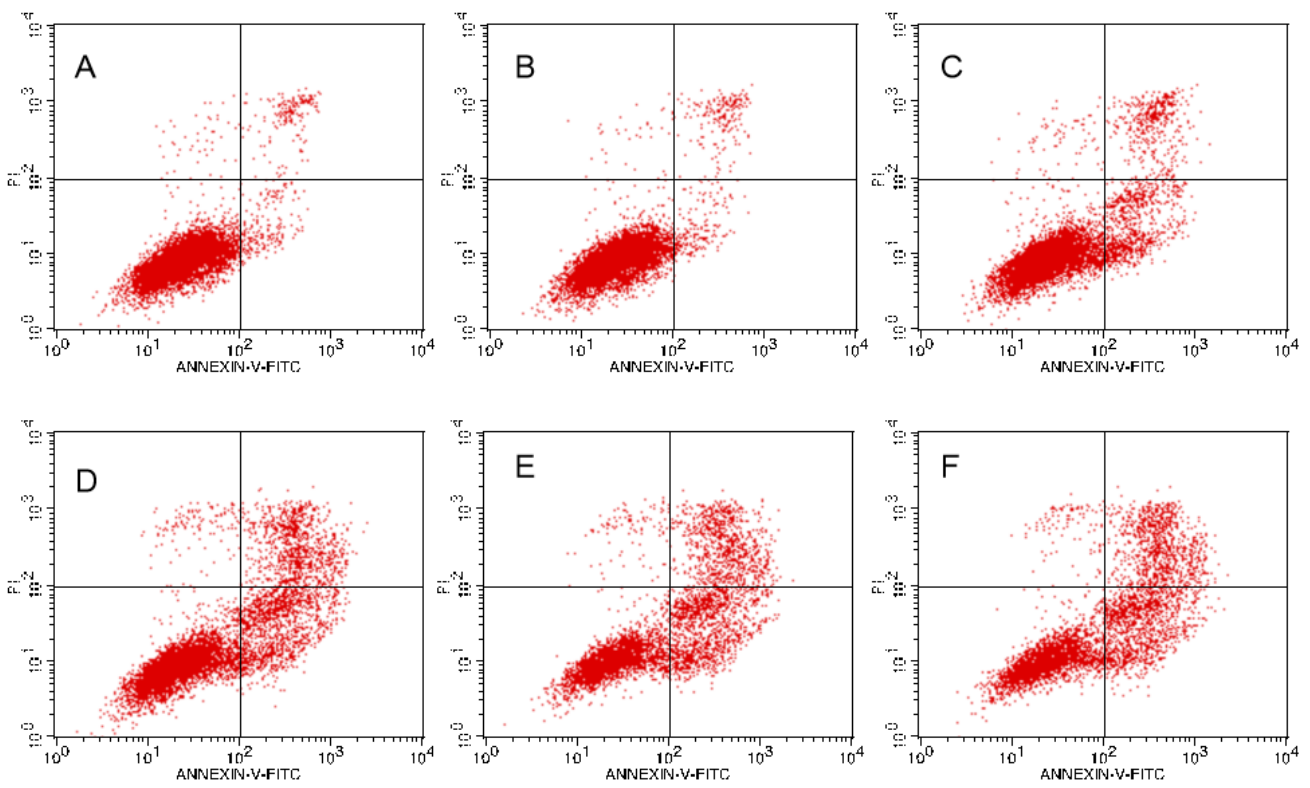

G

\begin{tabular}{|c|c|c|c|c|c|c|}
\hline groups & NCgroup & BL group & IGFBP 7 group & $5.0 \mu \mathrm{mol} / \mathrm{L}$ group & $10.0 \mu \mathrm{mol} / \mathrm{L}$ group & $20.0 \mu \mathrm{mol} / \mathrm{L}$ group \\
\hline $\mathrm{UL}(\%)$ & $0.61 \pm 0.03$ & $0.48 \pm 0.03$ & $1.86 \pm 0.12$ & $0.92 \pm 0.03$ & $1.6 \pm 0.05$ & $1.99 \pm 0.05$ \\
\hline UR+LR $(\%)$ & $4.84 \pm 0.45$ & $5.16 \pm 0.38$ & $40.52 \pm 1.76^{\mathrm{a}, \mathrm{b}}$ & $15.98 \pm 1.89^{\mathrm{a}}$ & $30.36 \pm 1.76^{\mathrm{ab} \text {, аa }}$ & $39.04 \pm 1.43^{\mathrm{ab}, \mathrm{aa}}$ \\
\hline $\operatorname{LL}(\%)$ & $94.55 \pm 1.89$ & $94.36 \pm 2.14$ & $57.61 \pm 2.01$ & $83.1 \pm 2.33$ & $66.03 \pm 2.98$ & $59.07 \pm 2.17$ \\
\hline
\end{tabular}

a: $\mathrm{P}<0.05$, the difference from the $\mathrm{NC}$ group was statistically significant

b: $\mathrm{P}<0.05$, the difference from the BL groups was statistically significant

aa: $\mathrm{P}<0.05$, the difference was statistically significant compared with the $5.0 \mu \mathrm{mol} / \mathrm{L}$ GA group aaa: $\mathrm{P}<0.05$, the difference was statistically significant compared with the $10.0 \mu \mathrm{mol} / \mathrm{L} \mathrm{GA}$ group

Figure 1. Comparison of apoptosis in six groups. (A is NC groups; $B$ is BL groups; $C$ is IGFBP7 transfection group; $D$ is $5.0 \mu \mathrm{mol} / \mathrm{L}$ GA group; $E$ is $10.0 \mu \mathrm{mol} / \mathrm{L}$ GA group; $F$ is $20.0 \mu \mathrm{mol} / \mathrm{L}$ GA group)

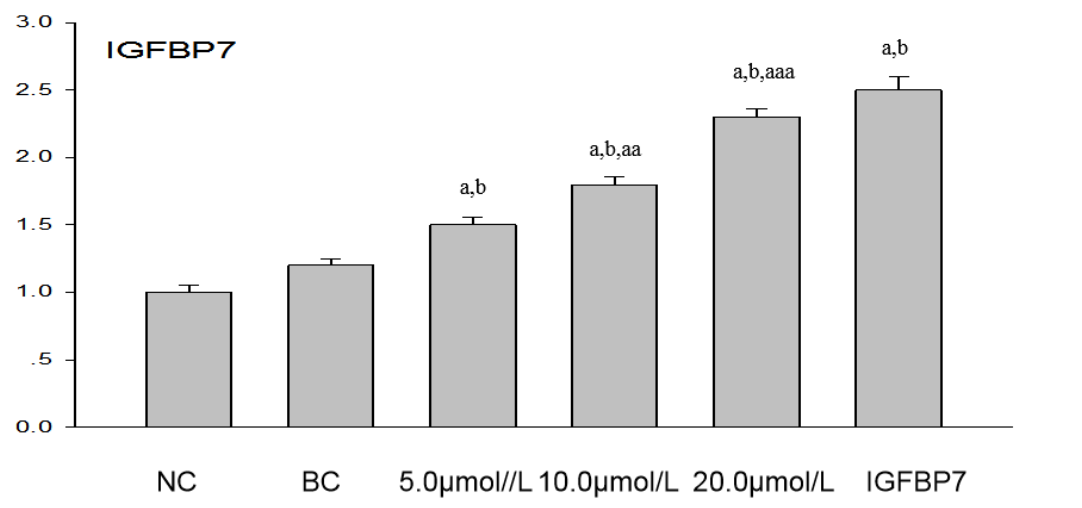

IGFBP7

$\beta$-actin

a: $\mathrm{P}<0.05$, the difference from the $\mathrm{NC}$ group was statistically significant b: $\mathrm{P}<0.05$, the difference from the BL groups was statistically significant aa: $\mathrm{P}<0.05$, the difference was statistically significant compared with the $5.0 \mu \mathrm{mol} / \mathrm{L} \mathrm{GA}$ group aaa: $\mathrm{P}<0.05$, the difference was statistically significant compared with the $10.0 \mu \mathrm{mol} / \mathrm{L}$ GA group

Figure 2. Comparison of six levels of IGFBP7 protein levels

APPLIED ECOLOGY AND ENVIRONMENTAL RESEARCH 18(5):6233-6241.

http://www.aloki.hu • ISSN 15891623 (Print) • ISSN 17850037 (Online)

DOI: http://dx.doi.org/10.15666/aeer/1805_62336241

(c) 2020, ALÖKI Kft., Budapest, Hungary 

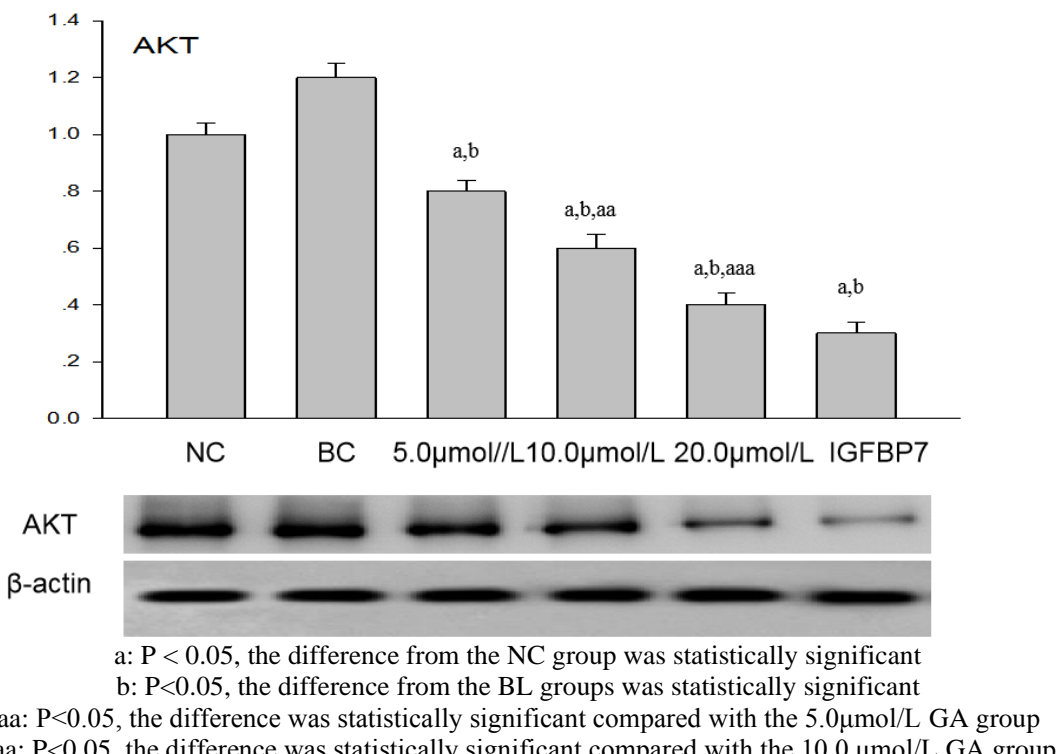

Figure 3. Comparison of six levels of AKT protein levels

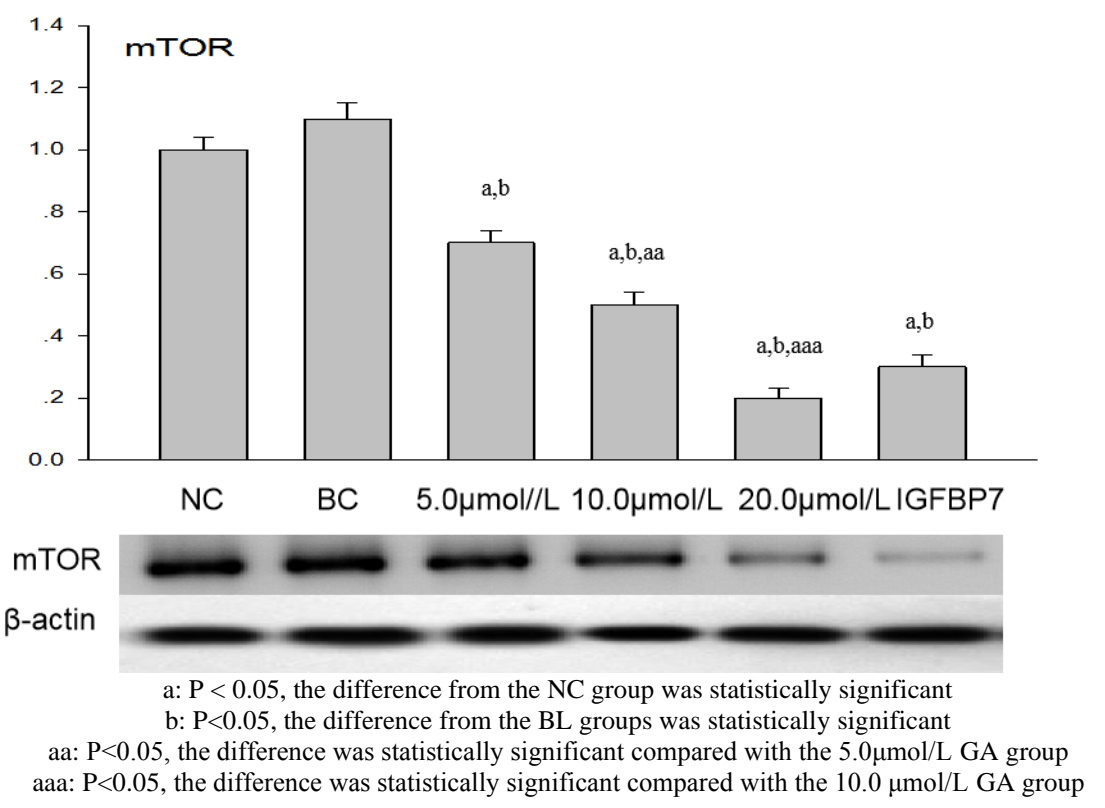

Figure 4. Comparison of six levels of mTOR protein levels

\section{Discussion}

IGFBP7, as a member of the IGFBP superfamily, plays an extremely important role in metabolic processes such as cell differentiation, proliferation and growth. A large number of studies have confirmed that the expression of IGFBP7 is related to the occurrence of various cancers (Wei, 2016; Chen, 2017; Kim, 2018; Akiel, 2017; Benassi, 2015), which is Many tumor suppressor factors. The data shows that IGF can bind to PI3K to produce protein kinase phosphorylation, activate the Akt/mTOR signaling pathway, and thereby promote cell proliferation, while IGFBP7 is an IGF binding protein 7 factor, which inactivates PI3K protein, inhibits Akt/mTOR signaling 
pathway, and produces cell inhibition role (Zhao, 2017; Xu, 2013). The results of this study suggest that the level of expression of IGFBP7 protein in prostate cancer PC-3 cells after treatment with different concentrations of pomegranate extract gallic acid group $(5.0 \mu \mathrm{mol} / \mathrm{L}$ group, $10.0 \mu \mathrm{mol} / \mathrm{L}$ group and $20.0 \mu \mathrm{mol} / \mathrm{L}$ group) and IGFBP7 overexpression group was significantly higher than the untreated group, but the corresponding AKT protein and mTOR protein expression levels were significantly lower than the untreated group. This result confirmed that the mechanism of pomegranate extract gallic acid inhibiting the proliferation of prostate cancer PC-3 cells may firstly enhance the expression of IGFBP7 protein, and then weaken the expression levels of AKT protein and mTOR protein, causing negative feedback of AKT/mTOR signaling pathway. It is related to regulation and eventually produces the inhibitory effect of tumor cells. However, whether the regulation of AKT/mTOR signaling pathway by gallic acid from pomegranate extract also blocks PI3K protein expression still needs further verification.

In the process of cell proliferation, differentiation, apoptosis and invasion, the AKT/mTOR signaling pathway plays a key role, and is an important signaling pathway in the process of tumor development (Wang, 2019; Zhao, 2019; Gasparri, 2018; Li, 2019). Data show that in the signal pathway of P13K/Akt/mTOR, the upstream pathway of $\mathrm{mTOR}, \mathrm{P} 13 \mathrm{~K}$ is phosphorylated by AKT protein to activate mTOR gene expression and promote tumor cell apoptosis (Gao, 2016; Johnson, 2018). The results suggest that the apoptosis rate of PC-3 cells treated with IGFBP7 protein expression group and pomegranate extract gallic acid group $(40.52 \pm 1.76,15.98 \pm 1.89,30.36 \pm 1.76$, $39.04 \pm 1.43)$ was significantly higher than the untreated $\mathrm{NC}$ and $\mathrm{BL}$ groups $(4.48 \pm 0.45,5.16 \pm 0.38)$, this result indicates that PC-3 cell apoptosis is related to AKT/mTOR signaling pathway. In addition, the inhibitory effect on prostate cancer PC3 cells has a significant dose-effect and time-effect relationship with the concentration and action time of pomegranate extract gallic acid. There were also some defects in this paper. Considering that pomegranate gallic acid also has certain toxicity to cells, the concentration is relatively low, and whether $20 \mu \mathrm{mol} / \mathrm{L}$ was its maximum effective concentration remains to be further discussed.

\section{Conclusion}

The study found that naturally-derived polyphenolic compounds play an important role in inhibiting the proliferation and migration of tumor cells, but there are certain differences in the reports of their mechanism of action (Wang, 2017; Estrela, 2017; Amani, 2017). This experiment used different concentrations of pomegranate extract gallic acid to treat prostate cancer PC-3 cells. It was found that pomegranate extract gallic acid can inhibit the expression level of AKT/mTOR protein by stimulating the expression of IGFBP7 and inhibit the AKT/mTOR signaling pathway Therefore, it has the effect of inhibiting the proliferation ability of PC-3 cells, and there is a significant dose-effect and time-effect relationship between this action trend and its concentration and action time. Studies have shown that compared with the NC and BL groups, the proliferation of PC-3 cells in the IGFBP7 transfection group and the three groups of pomegranate extract gallic acid was significantly reduced. The proliferative capacity of cells, as for the molecular mechanism of this result needs to be further explored. 
Acknowledgements. This study was supported by Academic support project for academic (professional) top talents in Anhui Province (gxbjZD80); Key Laboratory of Natural Science Research in Colleges and Universities of Anhui Province (KJ2019A1112; KJ2019A1117); In 2019, Hefei City academic and technical leaders and reserve candidates for research funding projects (Heren Social Affairs Office [2019]No.35); Anhui Provincial Department of Education Quality Engineering Project (2018ylzy131; 2019cxtd112).

\section{REFERENCES}

[1] Akiel, M., Guo, C., Li, X. et al. (2017): IGFBP7 deletion promotes hepatocellular carcinoma. - Cancer Res 77(15): 4014-4025.

[2] Amani, H., Ajami, M., Nasseri Maleki, S., et al. (2017): Targeting signal transducers and activators of transcription (STAT) in human cancer by dietary polyphenolic antioxidants. - Biochimie 142: 63-79.

[3] Benassi, M. S., Pazzaglia, L., Novello, C., et al. (2015): Tissue and serum IGFBP7 protein as biomarker in high-grade soft tissue sarcoma. - Am J Cancer Res 5(11): 344654.

[4] Chen, Y. B., Liao, X. Y., Zhang, J. B., et al. (2017): ADAR2 functions as a tumor suppressor via editing IGFBP7 in esophageal squamous cell carcinoma. - International Journal of Oncology 50(2): 622-630.

[5] Estrela, J. M., Mena, S., Obrador, E., et al. (2017): Polyphenolic phytochemicals in cancer prevention and therapy: bioavailability versus bioefficacy. - J Med Chem 60(23): 9413-9436.

[6] Feng, L. J., Yin, Y. L., Zhao, X. Q., et al. (2014): Research progress on metabolism and health function of gallic acid in pomegranate. - Journal of Fruit Science 31(4): 710-716.

[7] Gao, S., Yu, Y. (2016): Research on the relationship between mTOR signaling pathway and mechanism of tumorigenesis. - Foreign Medical Science Section of Medgeography 37(4): 353-356.

[8] Gasparri, M. L., Besharat, Z. M., Farooqi, A. A., et al. (2018): MiRNAs and their interplay with PI3K/AKT/mTOR pathway in ovarian cancer cells: a potential role in platinum resistance. - J Cancer Res Clin Oncol 144(12): 2313-2318.

[9] Guo, H. J., Zhang, D. Y., Fu, Q. (2016): Inhibition of cervical cancer by promoting IGFBP7 expression using ellagic acid from pomegranate peel. - Medical Science Monitor: International Medical Journal of Experimental and Clinical Research 22: 48814886.

[10] Hu, J. H., Chen, W. Y., Wang, X. F., et al. (2017): Functional study of insulin-like growth factor binding protein 7 in human gastric cancer SGC-7901. - Journal of Wenzhou Medical University,47(4): 296-298.

[11] Johnson, A. C. M., Zager, R. A. (2018): Mechanisms underlying increased TIMP2 and IGFBP7 urinary excretion in experimental AKI. - J Am Soc Nephrol 29(8): 2157-2167.

[12] Kim, J., Kim, W. H., Byeon, S. J., et al. (2018): Epigenetic downregulation and growth inhibition of IGFBP7 in gastric cancer. - Asian Pac J Cancer Prev 19(3): 667-675.

[13] Lee, J., Choi, K. H., Min, J., et al. (2017): Functionalized ZnO nanoparticles with gallic acid for antioxidant and antibacterial activity against methicillin-resistant S. aureus. Nanomaterials 7(11): 365.

[14] Li, N., Zhang, Z., Jiang, G., et al. (2019): Nobiletin sensitizes colorectal cancer cells to oxaliplatin by PI3K/Akt/MTOR pathway. - Front Biosci (Landmark Ed) 24: 303-312.

[15] Maleki, P., Sadeghi, Z., Shahryar, R. S., et al. (2020): MTT assay dataset of Polyethylenimine coated Graphenoxide nanosheets on breast cancer cell lines (MCF7, MDA-MB-231, MDA-MB-468). - Human Antibodies. DOI: 10.3233/HAB-200407.

[16] Momtaz, S., Niaz, K., Maqbool, F., et al. (2017): STAT3 targeting by polyphenols: novel therapeutic strategy for melanoma. - Biofactors 43(3): 347-370. 
[17] Pang, J. S., Yen, J. H., Wu, H. T., et al. (2017): Gallic acid inhibited matrix invasion and AP-1/ETS-1-Mediated MMP-1 transcription in human nasopharyngeal carcinoma cells. Int. J. Mol. Sci 18(7): 1354.

[18] Panth, N., Manandhar, B., Paudel, K. R. (2017): Anticancer activity of Punica granatum (pomegranate): a review. - Phytother Res 31(4): 568-578.

[19] Rasool, M. K., Sabina, E. P., Ramya, S. R., et al. (2010): Hepatoprotective and antioxidant effects of gallic acid in paracetamol-induced liver damage in mice. $-\mathrm{J}$ Pharm Pharmacol 62(5): 638-643.

[20] Sofia, L., Sana, Z., Noshabah, T., et al. (2018): Current practices and efficacy of improvements in radioactive management system of Pakistan. A review. - Environmental Contaminants Reviews 1(2): 09-12.

[21] Wang, J., Li, J., Wang, Y. (2019): Baicalein induces apoptosis of bladder cancer cells via inhibition of the PI3K/AKT/mTOR pathway. - Journal of Shandong University (Health Sciences) 57(9): 74-83.

[22] Wang, Q., de Oliveira, E. F., Alborzi, S., et al. (2017): On mechanism behind UV-A light enhanced antibacterial activity of gallic acid and propyl gallate against Escherichia coli O157: H7. - Scientific Reports 7(1): 8325.

[23] Wang, Z. (2017): NOP16 affects prostate cancer progression by ribosome synthesis. Master Thesis, China Tianjing Medical University, Tianjing.

[24] Wei, L. Y., Yue, C. Y., Peng, J. (2016): Effect of IGFBP7 overexpression on proliferation of breast cancer cell line MCF-7. - China Journal of Modern Medicine 26(6): 15-18.

[25] Xu, C. Z., Shi, R. J., Chen, D., et al. (2013): Potential biomarkers for paclitaxel sensitivity in hypopharynx cancer cell. - Int J Clin Exp Pathol 6(12): 2745-2756.

[26] Zhao, H. S., Chen, G., Ye, L., et al. (2019): DOK7V1 influences the malignant phenotype of lung cancer cells through PI3K/AKT/mTOR and FAK/paxillin signaling pathways. Int J Oncol 54(1): 381-389.

[27] Zhao, J. Y. (2017): Inhibitors of PI3K-AKT-mTOR signaling pathway and cancer immunotherapy. - Chin J Cancer Biother 24(12): 1424-1430.

[28] Zephania, N. F., Suiven John, P. T., Martin, F. (2019): Eucalyptus tree colonization of the Bafut-Ngemba Forest Reserve, North West Region, Cameroon. - Environment \& Ecosystem Science 3(2): 12-16. 